\title{
Effect of Germination on the Performance Characteristics of African Yam Bean (Sphenostylis stenocarpa Hochst ex A Rich) Seed Meal on Albino Rats
}

\section{ONWUKA, C FRANCIS; IKEWUCHI, C. CATHERINE; IKEWUCHI, C. JUDE*; AYALOGU, O. EDWARD}

Department of Biochemistry, Faculty of Science, University of Port Harcourt, P.M.B. 5323, Port Harcourt, Nigeria. (e-mail: ecoli240733@yahoo.com,Tel: +2348033715662)

\begin{abstract}
The performance characteristics or quality of protein from ungerminated and germinated African yam bean (Sphenostylis stenocarpa) seeds on male Wistar albino rats was investigated. The proteins were found to have high true digestibility (TD) and feed conversion ratio (FCR). The net protein retention (NPR), protein efficiency ratio (PER), protein retention efficiency (PRE), Net protein value (NPV), Nitrogen efficiency ratio (NER), feed efficiency ratio (FER) and relative NPR (RNPR) of the ungerminated seeds were significantly lower $(\mathrm{p}<0.05)$ than those of the germinated seeds, while their net protein utilization (NPU) were not significantly different. This implies a great potency of Sphenostylis stenocarpa seed protein as a source of high quality protein especially in the preparation of protein supplements and formulation of new diets: and the possibility of improvement by germination. @ JASEM
\end{abstract}

African yam bean (Sphenostylis stenocarpa) belongs to the family Papilionaceae. It is grown mainly in the Southern parts of Nigeria for its edible seeds. The Ibo people of South Eastern Nigeria call it "Okpodudu, Ijiriji, Azama". The seeds may be boiled and eaten with local seasoning, starchy, roots, tubers and fruit or converted to paste for the production of a type of "moi moi'. The seeds can also be roasted and eaten with palm kernel as snacks (Ezueh, 1984; Elegbede, 1998). It has medicinal value (Okeke et al., 2008). The quality of African yam bean seed protein has been studied in rats and chicks (Elegbede, 1998). However, the present study was designed to examine the effect of germination on the quality of African yam bean protein.

\section{MATERIALS AND METHODS}

Collection of Samples, Animals and Reagents: Sixteen, 23-24-day old weanling litter male Wistar albino rats (50-60), were procured from the Animal House of the Department of Biochemistry, University of Port Harcourt, Port Harcourt, Nigeria. They were maintained on guinea growers mash (Bendel Feed and Flour Mills Ltd., Ewu, Nigeria), for one week, prior to the commencement of the experiment. All chemicals are of analytical grades from Sigma, BDH, May and Baker, etc. Fresh samples of African yam bean (Sphenostylis stenocarpa Hochst ex A Rich) seeds were purchased from markets in Umuahia, Abia State, Nigeria. After due identification, they were rid of dirt, divided into two portions and stored.

Preparation of ungerminated and germinated African yam bean (Sphenostylis stenocarpa) meal (USM and GSM): The first portion was briefly soaked in water, after which they were dehulled by hand rubbing and gentle heating. They were then dried in an oven at $100^{\circ} \mathrm{C}$ for $12 \mathrm{~h}$, cooled and ground in a hand mill to pass an $80 \mathrm{~mm}$ mesh screen. The resultant powder hereinafter referred to as ungerminated African yam bean (Sphenostylis stenocarpa) meal (USM), was stored and subsequently used in compounding the test diets.

The second portion was soaked in water, drained and spread on a tray lined with damp cotton wool and Whatman No. 1 filter paper. The tray was covered with another damp filter paper and kept in a cupboard for 5 days for the seeds to germinate. The sprouts were dehulled and cleansed, after which they were dried and ground into powder and stored. This powder is hereinafter referred to as germinated African yam bean (Sphenostylis stenocarpa) meal (GSM), and was subsequently used in compounding the test diets.

Experimental Design: The animals were weighed, divided into four treatment groups $\left(T_{1}, T_{2}, T_{3}\right.$ and $\left.T_{4}\right)$ of four rats each, and housed individually in metabolic cages with wire mesh flour (to prevent coprophagia), and appropriate compartments to enable the collection of faeces and urine, as well as feed intake. Each treatment group was assigned one of four treatment diets, the composition of which is given in Table 1. $T_{1}$ received the reference diet whose protein source was $100 \%$ Nutrend $^{\mathrm{TM}}$ (from Nestle Foods Nigeria Plc.); $\mathrm{T}_{2}$ received the test diet whose protein source was $100 \%$ USM, $T_{3}$ received the test diet whose protein source was $100 \%$ GSM, while $T_{4}$ received the basal diet. All the diets were isoproteinic with protein contents of about 10\% (Table 2). The animals were allowed feed and water ad libitum and were weighed weekly. The daily feed intake was recorded, while the faeces were collected daily, and dried for analysis. After a 3-day acclimatization period on their respective diets, they were weighed before commencing the collection of faeces, and after another 7 days were again weighed and sacrificed. The feed, faecal and carcass nitrogen contents were 
analyzed according to standard methods (AOAC, 1980). The absorbed nitrogen, feed conversion ratio (FCR), feed efficiency ratio (FER), protein efficiency ratio (PER), net protein retention (NPR), relative NPR (RNPR), protein retention efficiency (PRE), net protein utilization (NPU), true digestibility (TD), biological value (BV), nitrogen efficiency ratio (NER) and net protein value (NPV) were all calculated as described by Pellett and Young (1980). The crude protein contents of the diets were determined according to standard methods (AOAC, 1980).

Statistical Analysis of Data: All values are quoted as the mean \pm S.D. The values of the various parameters for the various groups were analyzed for statistical significant differences using student's t test, with the aid of SPSS 17.0 package.
Table 1: Crude protein contents of the diets.

\begin{tabular}{ll}
\hline Component & $\begin{array}{l}\text { Composition } \\
\text { (\%) }\end{array}$ \\
\hline $\mathrm{T}_{1}$ & $13.56 \pm 0.01$ \\
$\mathrm{~T}_{2}$ & $9.84 \pm 0.01$ \\
$\mathrm{~T}_{3}$ & $9.88 \pm 0.02$ \\
\hline $\mathrm{T}_{4}$ & $6.56 \pm 0.02$ \\
\hline
\end{tabular}

Values are means \pm SD of three determinations.

Table 2: Composition of the experimental diets

\begin{tabular}{lllll}
\hline Component & \multicolumn{4}{c}{ Composition (\%) } \\
\cline { 2 - 5 } Nutrend $^{\mathrm{TM}}$ & $\mathrm{T}_{1}$ & $\mathrm{~T}_{2}$ & $\mathrm{~T}_{3}$ & $\mathrm{~T}_{4}$ \\
USM & 100.00 & - & - & - \\
GSM & - & 22.42 & - & - \\
Corn flour & - & - & 22.00 & - \\
Oil & - & 62.58 & 63.00 & 85.00 \\
\hline Mineral/vitamin & - & 10.00 & 10.00 & 10.00 \\
mix & - & 5.00 & 5.00 & 5.00 \\
\hline
\end{tabular}

Table 3: Performance characteristics of ungerminated and germinated African yam bean (Sphenostylis stenocarpa) meal on albino rats

\begin{tabular}{|c|c|c|c|}
\hline Parameter & & & Treatment \\
\hline & $\mathrm{T}_{1}{ }^{*}$ & $\mathrm{~T}_{2}{ }^{*}$ & $\mathrm{~T}_{3}{ }^{*}$ \\
\hline Food intake (g) & $63.88 \pm 15.38^{\mathrm{a}, \mathrm{b}}$ & $55.74 \pm 13.03^{\mathrm{a}}$ & $43.02 \pm 12.36^{b}$ \\
\hline Weight gain (g) & $23.64 \pm 5.87^{\mathrm{a}}$ & $1.33 \pm 0.48^{\mathrm{b}}$ & $2.84 \pm 0.77^{c}$ \\
\hline Protein intake (g) & $8.66 \pm 2.09^{\mathrm{a}}$ & $5.49 \pm 1.28^{\mathrm{b}}$ & $4.25 \pm 1.22^{\mathrm{c}}$ \\
\hline N intake (g) & $1.39 \pm 0.33^{\mathrm{a}}$ & $0.88 \pm 0.21^{b}$ & $0.68 \pm 0.20^{c}$ \\
\hline Faecal N (g) & $0.17 \pm 0.10^{\mathrm{a}}$ & $0.20 \pm 0.15^{\mathrm{a}}$ & $0.08 \pm 0.03^{\mathrm{a}}$ \\
\hline Carcass N (g) & $1.93 \pm 0.38^{\mathrm{a}}$ & $1.16 \pm 0.49^{\mathrm{a}, \mathrm{b}}$ & $0.94 \pm 0.22^{b}$ \\
\hline Absorbed N (g) & $1.22 \pm 0.25^{\mathrm{a}}$ & $0.68 \pm 0.09^{\mathrm{b}}$ & $0.61 \pm 0.12^{b}$ \\
\hline Retained N (g) & $1.12 \pm 0.37^{\mathrm{a}}$ & $0.35 \pm 0.05^{\mathrm{b}}$ & $0.13 \pm 0.02^{\mathrm{b}}$ \\
\hline Feed conversion ratio (FCR) & $2.71 \pm 0.02^{\mathrm{a}}$ & $47.06 \pm 19.02^{\mathrm{b}}$ & $16.44 \pm 6.96^{\mathrm{c}}$ \\
\hline Feed efficiency ratio (FER) & $0.37 \pm 0.00^{\mathrm{a}}$ & $0.03 \pm 0.02^{\mathrm{b}}$ & $0.07 \pm 0.04^{\mathrm{c}}$ \\
\hline Protein efficiency ratio (PER) & $2.73 \pm 0.02^{\mathrm{a}}$ & $0.27 \pm 0.15^{\mathrm{b}}$ & $0.74 \pm 0.35^{\mathrm{c}}$ \\
\hline Net protein retention (NPR) & $3.11 \pm 0.06^{\mathrm{a}}$ & $0.88 \pm 0.34^{\mathrm{b}}$ & $1.54 \pm 0.65^{c}$ \\
\hline Net protein utilization (NPU, \%) & $61.79 \pm 5.02^{\mathrm{a}}$ & $48.42 \pm 4.59^{\mathrm{a}}$ & $59.92 \pm 10.90^{\mathrm{a}}$ \\
\hline Relative NPR (RNPR, \%) & $100.00 \pm 0.00^{\mathrm{a}}$ & $28.30 \pm 10.93^{b}$ & $49.52 \pm 20.90^{c}$ \\
\hline Protein retention efficiency (PRE) & $49.76 \pm 0.96^{\mathrm{a}}$ & $14.08 \pm 5.44^{b}$ & $24.64 \pm 10.40^{c}$ \\
\hline True digestibility (TD, \%) & $86.18 \pm 1.82^{\mathrm{a}}$ & $97.71 \pm 1.81^{\mathrm{b}}$ & $98.57 \pm 1.26^{\mathrm{b}}$ \\
\hline Biological value (BV, \%) & $71.69 \pm 5.38^{\mathrm{a}}$ & $50.05 \pm 4.46^{\mathrm{b}}$ & $59.90 \pm 11.13^{\mathrm{a}, \mathrm{b}}$ \\
\hline Nitrogen efficiency ratio (NER) & $17.13 \pm 0.02^{\mathrm{a}}$ & $1.69 \pm 0.94^{\mathrm{b}}$ & $4.63 \pm 2.19^{c}$ \\
\hline Net protein value (NPV) & $837.87 \pm 0.62^{\mathrm{a}}$ & $476.45 \pm 0.48^{b}$ & $592.01 \pm 1.20^{\mathrm{c}}$ \\
\hline
\end{tabular}

*The relevant values are corrected and are means \pm SD, $n=$ four per group. Values in the same row with the different superscript are significantly different at $\mathrm{p}<0.05$.

\section{RESULTS AND DISCUSSION}

The performance characteristics of ungerminated and germinated African yam bean (Sphenostylis stenocarpa) meal protein is given in Table 3. The food intake of the animals on the GSM is significantly lower $(\mathrm{p}<0.05)$ than those on USM. However, both were not significantly different from those on the reference protein. The FCR of the test proteins were significantly $(\mathrm{p}<0.05)$ higher than the reference protein, with that of USM being the highest. The FER, NPR, RNPR, PRE, NER and NPV of the test proteins were significantly $(\mathrm{p}<0.05)$ lower compared to the reference protein, with that of USM being the least. The weight gain of the animals on USM was significantly $(p<0.05)$ the least, followed by those on GSM. This reduction in weight does not correlate with the food intake, and so implies that both USM and GSM can be used in weight reduction regimes. Weight reduction is one of the means of alleviating coronary risk incidence, diabetes mellitus, dyslipidemia, hypertension, obesity and physical functioning (Trussell et al., 2005; American Dietetic Association, 2005; Bantle et al., 2006; Krauss et al., 2006), and is one of the strategies for increasing low high density lipoprotein cholesterol (HDL-C) levels (NCEP, 2002; Assmann and Gotto, 2004), as well as improving insulin resistance (Krauss et al., 2006). Thus the significantly lower mean daily weight gain observed in the test animals, in this study, suggests the use of USM and GSM in the management of hypertension, obesity and dyslipidemia, with USM having the greater effect. 
The true digestibility of the test proteins were significantly $(\mathrm{p}<0.05)$ higher than that of the reference protein, as well as those reported for pigeon peas, lima beans, lentils, groundnuts, cowpeas, velvet beans, chick-peas, bambarra groundnuts and soybean (FAO, 1981). The biological value of the ungerminated seed protein was significantly $(p<0.05)$ lower than that of the reference protein, but not different from that of the germinated seeds. The BV of the USM is less than those of chick peas, bambarra groundnuts, cowpeas, soybeans, pigeon peas, lima beans and groundnuts, but greater than that of velvet beans and lentils; while that of the germinated seed protein is greater than those of velvet beans, lentils, groundnuts, bambarra groundnuts, pigeon peas and cowpeas, but less than those of chick peas, lima beans and soybeans (FAO, 1981).

There is no significant difference in the NPU of the three groups. The NPU of the ungerminated seed protein is greater than that of bambarra groundnuts, cowpeas, groundnuts, lentils and velvet beans, but less than those of lima beans, soybean and pigeon peas (FAO, 1981); while that of the germinated seed protein is greater than those of bambarra groundnuts, cowpeas, groundnuts, lentils, velvet beans, lima beans and pigeon peas, and comparable to that of soybean (FAO, 1981). The PER of the ungerminated seed protein is significantly lower $(p<0.05)$ than that of the germinated seed protein, and they are both significantly lower $(\mathrm{p}<0.05)$ than the reference protein, as well as the reported values for soybean, pigeon peas, lima beans, lentils, chick-peas and groundnuts (FAO, 1981).

In conclusion, our results suggest the possible use of both germinated and ungerminated African yam bean seed meals in the weight management, as well as a source of high quality protein. It also confirms the improvement of the performance characteristics by germination.

\section{REFERENCES}

A.O.A.C. (Association of Official Analytical Chemists) (1980). Official Methods of Analysis of the AOAC. Association of Official Analytical Chemists, Washington D.C., USA.

American Dietetic Association (2005). Disorders of Lipid Metabolism Evidence-Based Nutrition Practice Guideline. American Dietetic Association, Chicago (IL) August 2005. 17p.

Assmann, G; Gotto, AM Jr (2004). HDL Cholesterol and Protective Factors in Atherosclerosis. Circulation, 109[suppl III]:III-8-III-14.

Bantle, JP; Wylie-Rosett, J; Albright, AL; Apovian, CM; Clark, NG; Franz, MJ; Hoogwerf, BJ;
Lichtenstein, AH; Mayer-Davis, E; Mooradian, AD; Wheeler, ML (2006). Nutrition Recommendations and Interventions for Diabetes-2006: A position statement of the American Diabetes Association. Diabetes Care, 9(9):2140-2157.

Elegbede, JA (1998). Legumes. In: Osagie AU and Eka OU (ed), "Nutritional Quality of Plant Foods. Post Harvest Research Unit, Department of Biochemistry, University of Benin, Benin City, Nigeria. pp: 120-133.

Ezueh, MI (1984). African yam bean as a group in Nigeria. World Crops, 36(6): 199-200.

FAO (1981). Amino acid content of food and biological data on proteins. A report of FAO/UN joint Committee, Rome. P-84. ISBN 92-5001102-4.

Krauss, RM; Blanche, PJ; Rawlings, RS; Fernstrom, HS; Williams, PT (2006). Separate effects of reduced carbohydrate intake and weight loss on atherogenic dyslipidemia. Am. J. Clin. Nutr., 83(6):1025-1031.

NCEP (2002). Expert Panel on Detection, Evaluation, and Treatment of High Blood Cholesterol in Adults. Third Report of the National Cholesterol Education Program (NCEP) Expert Panel on Detection, Evaluation, and Treatment of High Blood Cholesterol in Adults (Adult Treatment Panel III). Final report. Circulation, 106(25):3143-3421.

Okeke, EC; Eneobong, HN; Uzuegbunam, AO; Ozioko, AO Kuhnlein, H (2008). Igbo Traditional Food System: Documentation, Uses and Research Needs. Pak J Nutr, 7(2): 365-376.

Pellett, PL; Young VR (ed), 1980. Nutritional evaluation of protein foods. Report of working group sponsored by the International Union of Nutritional Sciences and the United Nations University World Hunger Programme. United Nations University Press, The United Nations University. WHTR-3/UNUP-129. ISBN: 92808-0129-5.

Trussell, KC; Hinnen, D; Gray, P; Drake-Nisly, SA; Bratcher, KM; Ramsey, H; Early, J (2005). Case Study: Weight Loss Leads to Cost Savings and Improvement in Metabolic Syndrome. Diabetes Spectrum, 18(2): 77-79. 